TEME, г. XLII, бр. 3, јул - септембар 2018, стр. 763-778

Оригинални научни рад

DOI: $10.22190 /$ TEME1803763D

Примљено: 22. 7. 2017.

UDK 347.63

Ревидирана верзија: 15. 12. 2017.

Одобрено за штампу: 12. 6. 2018.

\title{
ИЗРАЖЕНОСТ И КОРЕЛАТИ КОНФЛИКТА РОДИТЕЉСКИХ И ПОСЛОВНИХ УЛОГА РОДИТЕЉА ${ }^{a}$
}

\author{
Марија Ђорђевић ${ }^{*}$ Марина Матејевић \\ Универзитет у Нишу, Филозофски факултет, Ниш, Србија \\ *djordjevic.marija990@gmail.com
}

\begin{abstract}
Апстракт
У раду се разматра израженост конфликта родитељских и пословних улога и повезаност са варијаблама као што су пол родитеља, ниво образовања и врста посла. Проблему кофликта приступа се кроз чувену теорију посао-породица конфликт, а то је модел Гринхауса и Бјутела (Greenhaus \& Beutell, 1985), према коме се утицај посла на породицу и обрнуто састоји од три субдимензије: временски базиран конфликт, конфликт базиран на напору, напрезању особе и карактеристикама особе и конфликт базиран на понашањима. У истраживању је учествовало 204 испитаника - запослених родитеља са бар једним дететом узраста од три године до 16 година са територије Србије. Добијени резултати указују на то да конфликт родитељских и пословних улога није изражен код родитеља у Србији, већ је изражен позитиван ефекат запослености. Дакле, показује се да запосленост родитеља позитивно утиче на породичну атмосферу. Значајне разлике показале су се у оносу на пол родитеља тако да конфликт напрезања имају више мајке него очеви. Такође, утврђено је да је позитиван ефекат запослености израженији код родитеља са вишим нивоом образовања, а мање изражен код родитеља са нижим нивоом образовања.
\end{abstract}

Кључне речи: временски конфликт, конфликт базиран на напрезању, конфликт базиран на понашању, конфликт родитељских и пословних улога, посао-породица.

\footnotetext{
${ }^{a}$ Рад је део макропројекта 179074, који је финансиран од стране Министарства за науку и технолошки развој.
} 


\title{
INTENSITY AND CORRELATES OF CONFLICT BETWEEN THE PARENT AND BUSINESS ROLES
}

\begin{abstract}
This paper addresses the issue of the intensity of the inter-role conflict regarding the parent and business roles and the relation between the conflict and variables: gender, level of education and type of work. The problem of the inter-role conflict is accessed through the famous model of job-family conflict, developed by Greenhaus \& Beutell (1985), according to which the impact of work on family and vice versa consists of three subdimensions: time-based conflict, the conflict based on effort, strain and characteristics of persons and conflict based on the behaviour. This research was performed among 204 participants - working parents with at least one child between the age of three and sixteen, from Serbia. The obtained results show that the participants do not express conflict between the parent and business roles, while they reported a positive employment effects. So, it shows that the parents' employment positively influences the family atmosphere. There were significant differences between the conflict based on strain, that were found between the male and female participants - the results showed a greater number of mothers who have conflict based on strain than the fathers. Also, differences were found regarding the parents' level of education - the positive employment effect is greater among parents with higher levels of education than the parents with lower levels of education.
\end{abstract}

Key words: conflict based on strain, conflict based on the behaviour, conflict between the parent and business roles, time-based conflict, work-family.

\section{УВОД}

Породица је социјална група заснована на сродству и заједници у којој се остварују различите везе и функције (Milić, 2001). Према системском приступу, породица је систем састављен од компоненти подсистема: партнерског, родитељског, супсистема који формирају деца, а истовремено је као целина део еколошког супрасистема са којим размењује енергију и информације. За разумевање начина на који функционише породица веома је важно разумевање односа који постоје између ових супсистема, као и однос између породице и околине у којем породица функционише. Примењујући општу теорију система на породицу и његово функционисање, може се рећи да се делови породице, односно супсистеми, налазе у сталном међусобном односу и да се понашање неких чланова, односно подсистема, не може разумети изоловано од другог дела супсистема. Такође је веома значајно истаћи да породица као систем делује кроз трансакционе обрасце који се састоје од поновљених интеракција које утврђују образац понашања. Ти обрасци, како каже Минућин (Minuchin \& Fishman, 1981, p. 12), употпуњавају породичну структуру која руководи функционисањем чланова породице, исцртавајући њихову скалу понашања и олакшавајући интеракцију међу њима. Потребна је животно способна породична структура у циљу испуња- 
вања основних задатака породице у подржавању индивидуације, уз истовремено пружање осећаја припадности.

Породица је, дакле, функционална група која током свог трајања треба да обавља разне променљиве задатке за своје чланове (Milić, 2001). Она као систем игра централну улогу у социјализацији, васпитању, психолошком и биолошком одржавању чланова породице, што подразумева три врсте задатака које породица треба да испуни: а) базичне задатке који се односе на обезбеђивање исхране и заштите чланова породице и базичне потребе на емоционалном плану кроз пружање подршке, љубави и разумевања за све чланове; б) развојни задаци односе се на подстицање раста и усавршавања чланова породице, и то давањем подршке кроз све фазе индивидуалног и породичног животног циклуса и в) задаци који се односе на прилагођавање и реаговање породице у ситуацијама када се појављују неочекивани догађаји: болест, смрт и развод. Породица би требало да амортизује поремећаје у економским и друштвеним збивањима и да даље пружа подршку за што је могуће безболнији раст и развој својих чланова (Goldner Vukov, 1988). Ове задатке породица треба да реализује у оквиру животног циклуса, који подразумева различите задатке у оквиру одређених фаза раста и развоја породице. У свом еволутивном развоју породица транзитира кроз различите фазе животног циклуса и сусреће се са бројним задацима које треба да савлада како би успешно транзитирала до следеће фазе раста и развоја. Веома је важно да породица препозна ове задатке и покрене одговаpajyће механизме за њихово решавање и успостављање хомеостазе. Неке породице решавају ове задатке, расту, развијају се и успешно прелазе из једне фазе развоја у следећу, док неке породице имају проблема у свом функционисању и развоју и успостављају патолошку хомеостазу. Функционална породица је породица која ствара услове за развој здравих и зрелих чланова у границама њихових интелектуалних и креативних потенцијала (Goldner Vukov, 1988). Функционалним се сматрају породични обрасци који омогућавају постизање породичних циљева које породица себи поставља. Дисфункционалним се сматрају породични обрасци којима се не испуњава задатак, већ долази до појаве симптома (недостатак емпатије, висок ниво љубоморе, неадекватне личне границе, непоштовање туђих граница) или незадовољства. Функционалност породице може се проучавати у односу на организационе процесе који подржавају интеграцију породице као целине. Елементи ових организационих процеса су кохезивност, флексибилност и комуникација. Функционалност породичног система можемо дефинисати преко следећих димензија: породичне флексибилности, која представља баланс између стабилности и промене, породичне кохезивности, која представља баланс између блискости и индивидуације, и породичне комуникације (Olson, 2000). 
Поред породице, као најзначајнијег система коме појединац припада, посао и обављање одређене делатности такође представља, ако се тако може рећи, други значајан систем у оквиру кога се очекује испуњавање одређених улога и реализовање личности. Између ових система успостављају се одређене релације, одређени односи који могу бити функционални или проблематични, могу допринети стварању хармоније у животу појединаца, или пак могу бити извор конфликта и утицати на процесе дезорганизације поменутих система, бити извор стреса и дестабилизовати и породично, и професионално, и лично функционисање.

Оваква ситуација побудила је истраживачку радозналост за настанак многобројних емпиријских истраживања (па и овог) која се баве испитивањем међусобне усклађености између родитељских и пословних улога и корелата који доприносе њиховом конфликту.

\section{КОНТЕКСТ ОДНОСА ПОСЛА И ПОРОДИЦЕ}

Посао и породица су два најважнија животна окружења за далеко највећи број људи у свету. При проучавању односа ова два феномена, морају се имати у виду сложена динамика глобалног друштва, промене које су резултат те динамике, као и све оне промене које настају у животном току чланова породице (Tomanović, 2009). Породица више није јединица производње као што је у сеоским друштвима живети у домаћинству значило и радити, али савремене породице настављају да производе, углавном, рад. Породица, наиме, производи рад двоструке природе - унутрашњи и спољашњи, кућни и плаћени. Због еманципације жена током 20. века, однос између ове две димензије коренито је измењен. Жене су ступиле на тржиште рада заједно са мушкарцима, мајчинској су додале и производну функцију. И док је 80-их година XX века све већи број жена присутан на тржишту рада, учешће мушкараца у кућним пословима не расте истим темпом (Segalan, 2009). Унутарпородични односи показали су највећи степен истрајавања традиционалног патријархалног обрасца, и то посебно у сфери поделе рада и моћи у домаћинству. Тако резултати домаћих истраживања показују да жене у просеку раде два и по сата више од мушкараца, те да чак $87 \%$ жена у Србији изјављује да се осећа преоптерећено радом (Milić i sar. 2010).

Све ово дефинише контекст у коме треба посматрати односе између посла и породице. У односу на нека ранија истраживања (Матејевић, 2009), нова истраживања (Матејевић, 2012) показују да се проценат функционалних породичних система смањио са $33,9 \%$ на $28,1 \%$, што указује на то да транзиција и економска криза веома неповољно утичу на функционалност породица, јер се проценат породица са обрасцима хаотичног функционисања повећао, због чега је 
неопходно да друштвена заједница покуша да пружи адекватнију подршку функционисању породице. С друге стране, оптимистички гледано, транзиција би, према дефиницији ауторке Трипковић (2004, стр. 206), „У извесном смислу била континуирани процес освајања и консолидације достигнутог нивоа друштвених промена у процесу модернизације”, односно „она се узима као нужна цена којом се плаћа напредак - то је улагање у будућност". Снажан пораст запослености жена, а нарочито све већи број образованих жена - значи један сасвим нови квалитет породице и односа у њој, јер је то сада породица са два храниоца, а не са једним храниоцем, како запажа Миливојевић (2014).

\section{ТЕОРИЈЕ О ОДНОСУ ПОСЛА И ПОРОДИЦЕ}

Повећано интересовање за ову проблематику почело је са почетком масовног запошљавања жена из средње класе (време Другог светског рата). Када су у питању истраживања у овој области, питања која су се постављала у вези са односом посла и породице била су да ли ситуација и карактеристике породице утичу на посао и који аспекти, или да ли посао утиче на квалитет породичног живота. Ипак, временом почиње да преовладава схватање да су породица и посао у ствари у интеракцији, а да смер утицаја у свакој конкретној ситуацији зависи од индивидуалне перцепције и конкретне ситуациje (Zedeck, 1987). Као резултат ових истраживања настало је више теорија о односу посла и породице. Неке од њих су:

1) Теорија преливања - оно што се дешава на послу прелива се и на породични живот. Односно, ако је особа задовољна на послу, биће задовољна и код куће или особа која ради досадан посао може на послу постати лења, па на основу новостечених вештина - избегавати обављање различитих породичних дужности. Према Задеку (Zedeck, 1987), у највећем броју истраживања у области односа посла и породице аутори се баве овом теоријом или полазе управо од ње. У оквиру ове теорије развили су се и други концепти као: концепт адитивности (позитивни ставови према послу побољшавају ставове према животу у принципу, негативни их погоршавају), концепт алијенације (ставови према послу директно утичу на осећања према животу уопште), когнитивно/бихевиорални поглед на ствари (посао је важна социјализујућа снага, захваљујући којој човек стиче бројне вештине, ставове, вредности, које онда исказује и у приватном животу);

2) Теорија компензације - постоји инверзан однос између посла и породице, те се људи различито инвестирају у ова два. По- 
родица и посао су повезани, али тако да особа ту врши компензацију - у једној сфери остварује, ради или добија оно што у другој сфери не може. Овде се помињу допунска компензација (када особа пожељне ствари којих нема довољно на послу тежи да оствари у оквиру породице) и реактивна компензација (када особа нпр. користи слободно време да би се одмарала од напорног посла). Дакле, негативне ствари са посла се обрађују или компензују у оквиру породице и у слободно време;

3) Теорија сегмената - посао и породица су независне сфере, одвојене просторно, временски и функционално и то омогућава њихово независно функционисање. Овај приступ претпоставља да је породица сфера интимности, афективности и интензивних међуљудских односа, док је посао сфера која је имперсонална, компетитивна и пре инструментална него експресивна;

4) Теорија инструменталности - посао и породица су повезани тако што је једна од ових сфера увек средство за постизање жељених резултата у оној другој - нпр., добри пословни резултати воде добром породичном животу и средство су за обезбеђивање различитих животних задовољстава;

5) Теорија конфликта - ове две сфере су уопштено гледано некомпатибилне и успех у једној сфери неминовно захтева жртве у другој сфери. Ово је услед тога што ове две сфере имају различите норме и захтеве;

6) Интегративна теорија - посао и породица су толико испреплетени да је немогуће посматрати их засебно.

Последњих 20 година, ипак, највећи број истраживања за предмет има проучавање конфликта између посла и породице, мада добар део истраживача не искључује могућност преливања, како запажа Хедрих у сопственој претрази Sciencedirect базе података (Vidanović, Todorović i Hedrih, 2006, стр. 22).

\section{ДЕФИНИСАЊЕ КОНФЛИКТА РОДИТЕЉСКИХ И ПОСЛОВНИХ УЛОГА}

Једна од чувених теорија посао-породица конфликта је и модел Гринхауса и Бјутела (Greenhaus \& Beutell, 1985). Она се ослања на рад Кана и сарадника (Kahn et al., 1964, p. 19), који су дефинисали конфликт улога као „истовремено присуство два (или више) скупа притисака, као кад усаглашавање са једним доводи до тежег усаглашавања са другим". Гринхаус и Бјутел (Greenhaus \& Beutell, 1985, p. 77) потом дефинишу конфликт радних и породичних улога као „облик сукоба међу улогама у којем су притисци радних и породичних улога вишеструко неспојиви" и према њима је посао-породица конфликт двосмеран и мултидимензионалан. Утицај посла на 
породицу и обрнуто састоји се од три субдимензије: временски базиран конфликт (када захтеви једне улоге чине физички немогућим испуњавање друге улоге), конфликт базиран на напору, напрезању особе и карактеристикама особе (када напор који особа улаже у једну улогу онемогућава испуњавање захтева који се очекују другом улогом) и конфликт базиран на понашањима (када су понашања везана за једну улогу некомпатибилна са очекивањима везаним за другу, истовремено постојећу улогу индивидуе).

Иначе, конфликт посла и породице значајан део аутора дели на конфликт посла и породице и конфликт породице и посла, по питању смера. Сходно томе су и Фрон и сарадници (Frone, Russel \& Barnes, 1996) најпре претпоставили да постоје два засебна облика сукоба радно-породичне улоге: рад-породица, тј. ометајуће деловање радне на породичну улогу, и породица-рад, тј. ометајуће деловање породичне улоге на радну. Такође, они су претпоставили да сваки од тих облика сукоба има два скупа специфичних узрока: узроци радпородица конфликта јесу заокупљеност радом и извори радног стре$\mathrm{ca}$, а узроци породица-рад конфликта јесу заокупљеност породицом и извори породичног стреса. Увидом у бројна истраживања може се закључити (Vidanović, Todorović i Hedrih, 2006) да постојање конфликта између посла и породице (а и обрнутог смера) има различите негативне последице, како по учинак на послу тако и на здравствено стање (стрес, изгарање) и разне психолошке варијабле (задовољство различитим аспектима живота). Аутори (Golubović, 1981) примећују да посао утиче на породицу двојако: обезбеђујући мање или више повољне услове за живот породице и реализујући (или ограничавајући) професионалне аспирације чланова породице. Ипак, на основу метаанализе већег броја досадашњих истраживања утврђено да је утицај посла на породични живот учесталији него што је то утицај породице на посао (Mesmer-Magnus \& Viswesvaran, 2005).

Задовољство појединца и перцепција о квалитету његових породичних улога умногоме је детерминисана квалитетом његових пословних улога. Поред социјалне функције рада, као основе за човекову егзистенцију, рад за човека је и нешто много више, то је основ за самореализацију човека, његову моћ и углед у друштву који му припада на основу рада. Наиме, ,рад је и извор друштвеног статуса и престижа..., уверења о властитој вредности, а за неке појединце може бити и извор самоостварења, стања у којем појединац постиже хармонијско испуњење својих креативних потенцијала" (Šverko i Galić, 2009: 197).

Следствено томе, можемо тврдити да су посао и породица два главна, чврсто испреплетана, градивна елемента која чине суштину, срж и окосницу живота готово сваког појединца, због чега ће усклађеност ова два елемента представљати кључ за успешан и квалитетан живот. 


\section{МЕТОДОЛОШКИ ОКВИР ИСТРАЖИВАЬА}

Циљ истраживања се односио на утврђивање изражености конфликта родитељских и пословних улога. У оквиру овог циља имали смо и три задатка, наиме, испитати повезаност конфликта и неких корелата - независних варијабли: пол родитеља, ниво образовања и врста посла родитеља. Општа претпоставка од које смо пошли јесте да је конфликт родитељских и пословних улога присутан код оба родитеља, али да је израженији код мајки. У истраживању је коришћена дескриптивна метода и скалирање као истраживачка техника. Коришћена је Скала процене изражености конфликта родитељске и пословне улоге, а у оквиру ње је коришћена Скала процене конфликта посао-породица (Kopelman, Greenhouse \& Connolly, 1983, p. 204), која садржи димензије: конфликт на послу, породични конфликт и конфликт улога; затим скраћена верзија Скале посао-nородица обогаћења (Cooklin et al., 2014, p. 269), која садржи димензије: посао-породица конфликт и посао-породица обогаћење; и скраћена и прилагођена верзија Мултидимензионалне скале конфликта посао-породиия (Carlson, Kacmar \& Williams, 2000, pp. 249276) са три субдимензије: временски базиран конфликт, конфликт базиран на напору, напрезању особе и карактеристикама особе и конфликт базиран на понашањима. Овако добијена скала има пет димензија које су у складу са издвојеним факторима у факторској анализи инструмента: Временски конфликт, Конфликт напрезања, Позитиван ефекат запослености, Конфликт понашања и Конфликт начина решавања проблема. Скала садржи 20 честица (нпр.: Пословни распоред ме често доводи до проблема организовања породичних активности; Мој рад на послу има позитиван ефекат на моју децу...). У питању је нумеричка скала, а бројеви у њој дефинисани су на следећи начин: 1. Никад, 2. Скоро никад, 3. Повремено, 4. Веома често, 5. Увек. На основу Кронбах-алфа теста (Cronbach's Alpha), уочили смо да на нашем узорку од 204 испитаника вредност Кронбах-алфа коефицијента инструмента за процену изражености конфликта родитељске и пословне улоге износи $\alpha=0,812$. Ова вредност добијена на нашем узорку је на задовољавајућем нивоу и показује да новоконструисана скала за потребе овог истраживања задовољава критеријум поузданости.

Истраживање је спроведено током 2016. године, и то прослеђивањем инструмента на друштвеној мрежи, дакле, родитељи су имали довољно времена, тј. онолико колико је сваком појединачно било потребно. 


\section{УЗОРАК ИСТРАЖИВАЬА}

Узорак овог истраживања чине запослени родитељи (који су у браку) са бар једним дететом узраста од три године до 16 година јер тада постоје велики захтеви у родитељској улози. Укупан број испитаника је 204. Структура испитаника приказана је у односу на независне варијабле истраживања: пол, ниво образовања и врста посла.

Табела 1. Структура узорка

\begin{tabular}{llrr}
\hline & & $\mathrm{F}$ & $\%$ \\
\hline Пол родитеља & Мушки & 46 & 22,5 \\
\multirow{2}{*}{ Ниво образовања } & Женски & 158 & 77,5 \\
& Основна & 2 & 1,0 \\
& Средња & 71 & 34,8 \\
Врста посла & Факултет & 131 & 64,2 \\
& Рад са људима & 77 & 37,7 \\
& Рад са стварима & 90 & 44,1 \\
Укупно & Рад са подацима & 37 & 18,1 \\
\hline
\end{tabular}

\section{РЕЗУЛТАТИ ИСТРАЖИВАҢА}

Први задатак истраживања био је да утврдимо ниво изражености конфликта између родитељских и пословних улога. Испитаницима је дато да процене колико често се сукобљавају са одређеним ситуацијама везаним за конфликт посла и породице. Резултати фреквенција и аритметичких средина показују основне вредности изражености конфликта између родитељских и пословних улога. Вредности нису високе готово ни код једне ставке која се односи на конфликт, већ само код оних које се односе на позитивне аспекте запослености родитеља. Можемо ово оценити као охрабрујућ податак за савремено друштво и савремену породицу. Наиме, вредности показују да конфликт између родитељских и пословних улога није изражен код наших испитаника. Из табеле видимо да су највише средње вредности код следећих ставки: Пословне и породичне одговорности ме чине комплетном особом $(\mathrm{AS}=4,49)$ и Пословне и породичне одговорности истовремено чине да се осећам компетентнијим (AS = $4,26)$. У овим тврдњама се око половине испитаника увек проналази.

Резултати такође показују и да су најниже средње вредности код ставки: Често сам емотивно празан када дођем кући са посла, што ме спречава да доприносим мојој породици $(\mathrm{AS}=1,89)$ и $C$ обзиром на све притиске на послу, кад дођем кући, под превеликим сам стресом да бих радио/ла ствари које ме испуњавају $(\mathrm{AS}=2,06)$. Видимо да су ово ставке које се односе на емотивни део конфликта, од- 
носно напрезање у конфликту улога. Међутим, више од трећине испитаника се на овим тврдњама изјашњава да никад нема ову врсту конфликта, што је позитивно знајући колико могући конфликт може деловати неповољно на родитељско функционисање.

Како би се лакше уочиле разлике у степену изражености конфликта између родитељских и пословних улога у односу на све испитиване варијабле, неопходно је било урадити факторску анализу. Задржано је свих 20 ставки подељених у пет фактора које смо именовали у складу са садржајем самих ставки.

Први фактор именован је као Временски конфликт због тога што овај фактор највише засићују ставови који указују на одвајање, спречавање, пропуштање и одузимање времена које би родитељи уместо на послу - проводили са породицом. Други фактор именован је као Конфликт напрезања због тога што овај фактор највише засићују ставови који указују на преокупираност, раздражљивост, неопуштеност и стрес услед посла. Трећи фактор именован је као Позитиван ефекат запослености због тога што овај фактор највише засићују ставови који указују на осећај комплетности и компетентности услед комбиновања посла и родитељства, позитиван ефекат и боље цењење времена које се проводи са децом. Четврти фактор именован је као Конфликт понашања због тога што овај фактор највише засићују ставови који указују на понашање ефективно у послу, које је контрапродуктивно код куће са децом. Пети фактор именован је као Конфликт у обављаюу активности због тога што овај фактор засићују ставови који указују на умор и проблем организовања породичних активности услед посла. Ови фактори коришћени су као димензије конфликта пословних и родитељских улога у анализи резултата.

У оквиру наредног задатка нашег истраживања, на основу $\mathrm{F}$ теста, уочили смо да не постоји статистички значајна разлика у степену изражености било ког конфликта између испитаника чији посао представља рад са људима, рад са стварима и рад са подацима.

Следећи задатак нашег истраживања био је да утврдимо повезаност конфликта родитељских и пословних улога и пола родитеља, за шта смо користили t-тест.

Из Табеле 2 можемо уочити да постоји статистички значајна разлика $(\mathrm{p}<0,05)$ у степену изражености једино димензије конфликта напрезања $(\mathrm{t}=-2,068, \mathrm{df}=202, \mathrm{p}=0,040)$. Резултати показују да конфликт напрезања имају више мајке него очеви. С обзиром на то да су жене на себе преузеле двоструки посао - посао раднице и посао домаћице, овакви резултати су очекивани. 
Табела 2. Повезаност конфликта родитељских и пословних улога и пола родитеља

\begin{tabular}{|c|c|c|c|c|c|c|}
\hline & & AS & SD & $\mathrm{t}$ & df & $\mathrm{p}$ \\
\hline \multirow{2}{*}{ Временски конфликт } & Мушки & 2,42 & 0,72 & \multirow{2}{*}{0,417} & \multirow{2}{*}{84,754} & \multirow{2}{*}{0,678} \\
\hline & Женски & 2,37 & 0,84 & & & \\
\hline \multirow{2}{*}{ Конфликт напрезања } & Мушки & 2,07 & 0,69 & \multirow{2}{*}{$-2,068$} & \multirow{2}{*}{202} & \multirow{2}{*}{$0,040^{*}$} \\
\hline & Женски & 2,36 & 0,89 & & & \\
\hline \multirow{2}{*}{$\begin{array}{l}\text { Позитиван ефекат } \\
\text { запослености }\end{array}$} & Мушки & 4,07 & 0,86 & \multirow{2}{*}{$-0,483$} & \multirow{2}{*}{62,543} & \multirow{2}{*}{0,631} \\
\hline & Женски & 4,14 & 0,69 & & & \\
\hline \multirow{2}{*}{ Конфликт понашања } & Мушки & 2,54 & 0,97 & \multirow{2}{*}{0,471} & \multirow{2}{*}{68,975} & \multirow{2}{*}{0,639} \\
\hline & Женски & 2,47 & 0,89 & & & \\
\hline \multirow{2}{*}{$\begin{array}{l}\text { Конфликт у обављању } \\
\text { активности }\end{array}$} & Мушки & 2,59 & 0,81 & \multirow{2}{*}{$-0,825$} & \multirow{2}{*}{81,140} & \multirow{2}{*}{0,412} \\
\hline & Женски & 2,70 & 0,91 & & & \\
\hline
\end{tabular}

Последњи задатак истраживања био је да утврдимо повезаност конфликта родитељских и пословних улога и нивоа образовања родитеља, за шта смо користили F тест.

Табела 3. Повезаност конфликта родитељских и пословних улога и нивоа образовањ а родитеља

\begin{tabular}{|c|c|c|c|c|c|c|}
\hline & & AS & SD & $\mathrm{F}$ & df & $\mathrm{p}$ \\
\hline \multirow{4}{*}{$\begin{array}{l}\text { Временски } \\
\text { конфликт }\end{array}$} & Основна & 2,64 & 1,72 & \multirow{4}{*}{0,941} & \multirow{4}{*}{2} & \multirow{4}{*}{0,392} \\
\hline & Средња & 2,48 & 0,84 & & & \\
\hline & Факултет & 2,32 & 0,79 & & & \\
\hline & Укупно & 2,38 & 0,81 & & & \\
\hline \multirow{4}{*}{$\begin{array}{l}\text { Конфликт } \\
\text { напрезања }\end{array}$} & Основна & 2,63 & 0,53 & \multirow{4}{*}{0,167} & \multirow{4}{*}{2} & \multirow{4}{*}{0,846} \\
\hline & Средња & 2,28 & 0,85 & & & \\
\hline & Факултет & 2,30 & 0,86 & & & \\
\hline & Укупно & 2,30 & 0,85 & & & \\
\hline \multirow{4}{*}{$\begin{array}{l}\text { Позитиван } \\
\text { ефекат } \\
\text { запослености }\end{array}$} & Основна & 3,50 & 0,00 & \multirow{4}{*}{5,003} & \multirow{4}{*}{2} & \multirow{4}{*}{$0,008 * *$} \\
\hline & Средња & 3,93 & 0,83 & & & \\
\hline & Факултет & 4,24 & 0,65 & & & \\
\hline & Укупно & 4,12 & 0,73 & & & \\
\hline \multirow{4}{*}{$\begin{array}{l}\text { Конфликт } \\
\text { понашања }\end{array}$} & Основна & 3,67 & 0,00 & \multirow{4}{*}{1,965} & \multirow{4}{*}{2} & \multirow{4}{*}{0,143} \\
\hline & Средња & 2,41 & 1,01 & & & \\
\hline & Факултет & 2,51 & 0,85 & & & \\
\hline & Укупно & 2,49 & 0,91 & & & \\
\hline \multirow{4}{*}{$\begin{array}{l}\text { Конфликт у } \\
\text { обављању } \\
\text { активности }\end{array}$} & Основна & 2,75 & 1,77 & \multirow{4}{*}{0,586} & \multirow{4}{*}{2} & \multirow{4}{*}{0,557} \\
\hline & Средња & 2,77 & 0,79 & & & \\
\hline & Факултет & 2,63 & 0,94 & & & \\
\hline & Укупно & 2,68 & 0,89 & & & \\
\hline
\end{tabular}


Из Табеле 3 можемо уочити да постоји статистички значајна разлика $(\mathrm{p}<0,01)$ у степену изражености једино димензије позитивног ефекта запослености $(\mathrm{F}=5,003, \mathrm{df}=2, \mathrm{p}=0,008)$. Резултати показују да позитиван ефекат запослености примећују родитељи са завршеном вишом школом, односно факултетом, а најмање родитељи са завршеном основном школом. Дакле, виши ниво образовања родитеља доводи до позитивног ефекта запослености. Овај резултат може се протумачити могућношћу да родитељи са вишим нивоом образовања могу пре да се остваре, те буду задовољни собом. Родитељи који су задовољни собом лакше остварују баланс између посла и породице.

\section{ДИСКУСИЈА}

Резултати које смо добили у складу су са резултатима неких ранијих истраживања која су се бавила проблемима функционисања родитеља. Неки аутори (Barnett \& Rivers, 1996) наводе да студије спроведене на америчким породицама код којих су оба родитеља запослена пуно радно време указују на то да ове породице и поред извесних породичних проблема могу бити врло функционалне. Позитивни исходи које мајкама и очевима доноси запосленост су мањи степен депресивних симптома и анксиозности који су били карактеристични за жене 50-их година XX века. Мушкарци који су очеви нису дистанцирани и искључиво раду посвећени као што је то био случај у XX веку. И мушкарци и жене наводе да су њихови односи са децом топли и да су целокупно задовољни својом улогом родитеља. Овакви налази указују на могућност позитивног балансирања између породичних и пословних захтева.

Налаз да конфликт напрезања имају више мајке него очеви делује у складу са неким истраживањима конфликта посла и породице (Carlson, Kacmar \& Williams, 2000) у којима су аутори нашли да жене показују виши ниво конфликта базираног на времену, напору (напрезању) и понашању у смеру породица-посао и виши ниво конфликта базираног на напору (напрезању) у смеру посао-породица, у односу на мушкарце. Такође, домаћа истраживања (Mihić, Mihić i Spasojević: 2011) показују да жене имају снажније изражен конфликт породица-посао на све три подскале конфликта (конфликт напрезања, времена и понашања), с тим да је најизраженији на супскали времена, што аутори објашњавају очекивањима да жена буде и успешна мајка и домаћица, поред тога што је и запослена, а што одузима време које оне желе да посвете породици. Дакле, код жена је конфликт израженији. Трансформација након индустријализације, која је довела до запошљавања жена, истовремено је задала ударац традиционалном устројству породице (где се отац бавио послом, а жена де- 
цом). Сада оба члана породице имају и значајна породична задужења, оба партнера могу бити запослена, па је потребно организовати прерасподелу кућних послова (Vidanović, Todorović i Hedrih, 2006). Очекивано, мушкарци би сада требало да су укљученији у одгајање деце и обављање кућних послова. Међутим, домаћа истраживања (Petrović и сар.: 2009) показују да жене и поред тога што раде и зараЂују, три пута више учествују у уређивању и организовању породичних активности, за разлику од мушкараца, чија је улога описана као помоћ. Све ово говори о томе да је жена члан породице који мора уложити највише енергије (што је у нашем случају фактор напрезања) како би успоставила добру и здраву равнотежу између пословне и породичне улоге.

Резултати који показују да виши ниво образовања родитеља доводи до позитивног ефекта запослености поклапају се са емпиријским увидима који показују да део удела жене у кућним пословима опада уколико расте ниво образовања оба супружника (Goldscheiden $\&$ Waite, 1991) и мишљењем појединих аутора (Viers \& Prouty, 2001) који објашњавају разлику између породица где двоје људи гради каријеру и породица у којима двоје људи зарађују новац. Основна разлика је у томе што парови који граде каријеру имају виши едукативни ниво, више личне посвећености, низ серија промотивних циклуса, више психолошке укључености у посао и посвећености њему. Жене које раде због потребе, најчешће финансијске природе, имају виши ниво тензије и нижи ниво задовољства у пару, за разлику од жена које граде каријеру и бирају да буду запослене.

\section{ЗАКЉУЧНА РАЗМАТРАЬА}

На крају, може се рећи да, иако смо пошли од претпоставке да запосленост родитеља неминовно доводи до конфликта родитељских и пословних улога, ипак, показало се да родитеље пословне и породичне одговорности чине комплетном особом и чине да се осећају компетентнијим. Рад на послу помаже им да боље цене време које проводе са својом децом. Резултати су, дакле, више у складу са теоријом преливања него са теоријом конфликта, од које смо пошли. Овакви налази указују на светлију страну запошљавања и рада у породици и нуде нове погледе на могућност позитивног балансирања породичним и пословним захтевима.

Конфликт родитељских и пословних улога није повезан ни са једном врстом посла, јер не постоји статистички значајна разлика у степену изражености конфликта.

Резултати су показали да конфликт напрезања имају више мајке него очеви. С обзиром на то да су жене на себе преузеле двоструки посао - посао раднице и посао домаћице, овакви резултати били су оче- 
кивани. Запошљавањем, жене су морале да се прилагоде на своју нову улогу (да раде као мушкарци), а притом да испуњавају и своју традиционалну улогу којој су учене од детињства. Дакле, због тога је управо жена (мајка) тај члан породице који мора уложити највише енергије (што је у нашем случају фактор напрезања) како би успоставила добру и здраву равнотежу између пословне и породичне улоге.

Позитиван ефекат запослености израженији је код родитеља са вишим нивоом образовања, а мање је изражен код родитеља са нижим нивоом образовања. Овај резултат може се протумачити могућношћу да родитељи са вишим нивоом образовања могу пре да се остваре, те буду задовољни собом. Родитељи који су задовољни собом лакше остварују баланс између посла и породице.

Видимо да породица успева да амортизује поремећаје у економским и друштвеним збивањима и да пружа подршку за што је могуће безболнији раст и развој својих чланова. Резултати овог истраживања имплицирају значај родитељских компетенција како би могли да на адекватан начин одговоре на захтеве нових бројних обавеза везаних за родитељско функционисање.

Ово истраживање отвара нам и нове истраживачке могућности. С обзиром на то да смо констатовали да запосленост родитеља позитивно утиче на породичну атмосферу, можемо истражити и могућност утицаја неке треће појаве, као што је темперамент особе или нешто слично. Предмет могу бити и последице конфликта родитељских и пословних улога по развој деце. Све би ово допринело расветљавању овог проблема са више аспеката.

\section{ЛИТЕРАТУРА}

Barnett, R. C. \& Rivers, C. (1996). She works, he works: How two-income families are happy, healthy, and thriving. Cambridge, MA: Harvard University Press.

Vidanović, S., Todorović, J. i Hedrih, V. (2006). Porodica i posao - izazovi $i$ mogućnosti [Family and work - challenges and opportunities]. Niš: Filozofski fakultet.

Viers, D. \& Prouty, A. (2001). We've Come a Long Way? An Overview of Research of Dual Career Couples' Stressors and Strenths. The Haworth Press.

Goldner Vukov, M. (1988). Porodica u krizi [Family in crisis]. Beograd: Medicinska knjiga.

Goldscheiden, F. K. \& Waite, L. (1991). New families, NO Families. Berkeley, University of California Press.

Golubović, Z. (1981). Porodica kao ljudska zajednica [Family as a human community]. Zagreb, Naprijed.

Greenhaus, J. H. \& Beutell, N. J. (1985). Sources of conflict between work and family roles. Academy of Management Review, 10, 76-88.

Zedeck, S. (1987). Work, Family, and Organizations: An Untapped Research Triangle. Institute of Industrial Relations. Institute of Industrial Relations Working Paper Series. 
Kahn, R. L., Wolfe, D. M., Quinn, R., Snoek, J. D., \& Rosenthal, R. A. (1964). Organizational stress. New York: Wiley.

Kopelman, R.E., Greenhouse J.H. \& Connolly T.F. (1983). A model of Work, Family and Interrole Conflict: A Construct Validation Study. Organizational Behavior and Human Performance, 32, 198-215. doi: 10.1016/00305073(83)90147-2

Матејевић, М. (2012). Функционалност породичних система и васпитни стил родитеља у породицама са адолесцентима [Family system functionality and educational styles of parents in families with adolescents]. Настава $u$ васпитань, 1, 128-141.

Матејевић, М. (2009). Функционалност породица студената и склоност ка алкохолизму и наркоманији [The functionality of the student's family and alcoholism and drug addiction]; У Студенти, секс и дрога, Зборник радова (149-160). Центар за научна истраживања САНУ и Универзитет у Нишу.

Mesmer-Magnus, J. \& Viswesvaran, C. (2005). Convergence between measures of work-to-family and family-to-work conflict: A meta-analytic examination. Journal of Vocational Behavior. 67 (2), 215-232.

Миливојевић, С. (2014). Промене у савременом породичном животу и трансформација породице и домаћинства [Changes in modern family life and transformation of family and family life]; У Зборник радова Филозофског факултета 44 (3) (241-253). doi:10.5937/ZRFFP44-702

Milić, A. (2001). Sociologija porodice: kritika i izazovi [Sociology of the family: the criticism and challenges]. Beograd, Čigoja štampa.

Milić, A., S. Tomanović, M. Ljubičić, N. Sekulić, M. Bobić, V. Miletić-Stepanović i Stanojević D. (2010). Vreme porodica: sociološka studija o porodičnoj transformaciji u savremenoj Srbiji [Family time: a sociological study of family transformation in contemporary Serbia]. Beograd, Institut za sociološka istraživanja Filozofskog fakulteta u Beogradu: Čigoja.

Minuchin, S. \& Fishman H. C. (1981). Family therapy Techniques. Harvard University Press.

Mihić, V., Mihić, I. i Spasojević, A. (2011). Konflikt porodičnih i profesionalnih uloga: rodna perspektiva [Conflicts of family and professional roles: a gender perspective]; U Mihić, I. i Zotović M. (ur.). Porodične i profesionalne uloge: značaj zaposlenja za porodično funkcionisanje (49-57). Novi Sad: Filozofski fakultet.

Olson, D. H. (2000). Circumlex Model of Marital and Family Sistems. Journal of Family Therapy, 22, 144-167.

Petrović, J., Mihić, I., Zotović, M. \& Kapor-Stanulović, N. (2009). Family Roles of Father and Mother in the Families in the Process of Transition. Zbornik Matice srpske za društvene nauke, 128 (31-45).

Carlson, D. S., Kacmar, K. M. \& Williams, L. J. (2000). Construction and Initial Validation of a Multidimensional Measure of Work-Family Conflict. Journal of Vocational Behavior, 56, 249-276.

Segalan, M. (2009). Sociologija porodice [Sociology of the family]. Beograd, CLIO

Cooklin, A. R., Westrupp, E., Strazdins, L., Giallo, R., Martin, A. \& Nicholson, J. M. (2014). Mothers' Work-Family Conflict and Enrichment: Associations with Parenting Quality and Couple Relationship. Child: Care, Health and Development, 41 (2), 266-277. doi:10.1111/cch.12137

Tomanović, S., (2009). Promene u porodicama [Changes in families]; U Milić, A., Tomanović, S. (ur.). Porodice u Srbiji danas u komparativnoj perspektivi (151-168), Institut za sociološka istraživanja Filozofskog fakulteta u Beogradu. 
Трипковић, Г. (2004). Породица у транзицији [Family in transition]. Социолошки преглед, 38, 1-2, 205-218.

Frone, M. R., Russel, M. \& Barnes, G. M. (1996). Work-family conflict, gender, and health-related outcomes: a study of employed parents in two community samples. Journal of Occupational Health Psychology, 1(1): 57-69.

Šverko, B. i Galić, Z. (2009). Kvaliteta radnog života u Hrvatskoj: subjektivne procjene tijekom posljednjih 15 godina [Quality of working life in Croatia: subjective ratings during the last 15 years]; In Franičević, V. i Puljiz, V. (eds.). Rad u Hrvatskoj: pred izazovima budućnosti (197-223). Zagreb: Centar za demokraciju i pravo Miko Tripalo i Pravni fakultet Sveučilišta u Zagrebu.

\title{
INTENSITY AND CORRELATES OF CONFLICT BETWEEN THE PARENT AND BUSINESS ROLES
}

\author{
Marija Đorđević, Marina Matejević \\ University of Niš, Faculty of Philosophy, Niš, Serbia
}

\section{Summary}

The modern family is facing many new challenges as a result of an extreme crisis and profound change that has its own peculiarities in our transitional environment. The development of technology and changes in the organization of work in the contemporary society that has occurred in recent decades carry as a result the emergence of conflicts in the work-family area.

This paper addresses the issue of the intensity of the inter-role conflict regarding the parent and business roles. We had three tasks within the goal of our research - examining the relationship between conflict and independent variables: the parents' gender, level of education and the type of job. In order to determine more easily the differences between the levels of conflict among parental and business roles regarding all mentioned variables, the factor analysis was conducted. The Lickert scale assessing the level of parental and business roles conflict, which was specifically designed for the purposes of this study, set aside five factors - dimension of the conflict: Time conflict, Stress conflict, Positive effect of employment, Behavioral conflict and Conflict in performing activities. The study included 204 participants - working parents with at least one child, three to 16 years old, on the territory of Serbia.

The results indicate that the parents in Serbia do not express parental and business roles conflict, in fact, the positive effect of employment is being expressed among these parents. Parental and business roles conflict was not related to any specific type of job, but the results did show that mothers express more stress conflict that fathers do. Regarding the fact that women are taking upon themselves a double job - job of a worker and a housekeeper, these results were expected. The positive employment effect is higher among parents with higher education levels than the parents with lower levels of education. Our interpretation of these results is that it is possible that the parents with higher levels of education could achieve their goals sooner than the parent with lower levels of education, thus these parent are more satisfied wtih themselves. The parents who are satisfied with themselves achieve more easily a balance between work and family. 